\title{
Labour Force Participation of Older Workers in Italy: Trends, Causes and Policy Issues
}

\author{
Dario Focarelli and Paolo Zanghieri \\ ANIA - Research Unit, Via della Frezza, 70, Rome 00186, Italy. \\ E-mail: Paolo.Zanghieri@ania.it
}

Population ageing in Italy is more pronounced than in most of the other developed countries. Given the very low employment rate for older workers, this is likely to have a negative effect on overall labour force participation in the near future. This paper describes the demographic and labour-market trends for people older than 50, making some comparisons between Italy and other EU countries. It then offers some evidence on the determinants of the individual choice of retirement by looking at some econometric studies showing that the generosity of the public pension scheme is crucial. Finally, the policy measures adopted during the last decade to raise the retirement age are reviewed: the broad pension reforms implemented over the years may have had some effect by curbing pension benefits, but none of the possible alternative measures taken in other European countries has been implemented.

The Geneva Papers (2005) 30, 711-723. doi:10.1057/palgrave.gpp.2510047

Keywords: labour market; older workers; retirement; pension system

JEL classification: J14; J21; J26

\section{Introduction}

Coping with the economic effects of population ageing is certainly one of the most important policy issues that governments in OECD countries will have to face in the years and decades ahead. The impact of ageing on economic activity and government finances in developed economies has been the subject of extensive analysis. ${ }^{1}$ Here, we focus on Italy and the changes in labour force participation. The paper provides a concise picture of the phenomenon and describes the measures taken by the successive Italian Governments to deal with it.

The Italian population is ageing more rapidly than that of most EU countries. While the long-term effect on the pension system has been at least attenuated by the series of pension reforms enacted during the 1990s, much must still be done to prevent a strong and negative impact on labour supply, and hence, on long-term growth.

The paper is organized as follows. The next section sketches the main demographic trends and their impact on employment. The evidence drawn from microeconometric studies of retirement behaviour and some of the various possible policy measures and

\footnotetext{
${ }^{1}$ See for example, Turner et al. (1998) and McMorrow and Roeger (2003).
} 
their implementation are detailed in the subsequent section. Our conclusions are summarized in the final section.

\section{Motivations}

Italy has one of the world's highest old-age dependency ratios (the ratio between the population older than 65 to the one younger than 16) and it is rising faster than elsewhere (Table 1). The factors determining this trend are well known: increasing life expectancy and the consequences of the baby boom, which occurred during the late 1950s-early 1960s (and consequent bust), on the age structure of the active population, and finally the sharp decrease in the fertility rate.

The population share of the age group slated for workforce entry, aged 15-24, shrank considerably between 1991 and 2001, while the older age groups are expanding, as shown by Table 2. Between 2000 and 2050, average life expectancy at retirement will rise by 4 years, the gain being greater for women.

The impact of these factors on labour supply depends on the behaviour of agespecific participation rates. If they are constant over time, then the total workforce will contract sharply in the next decade. However, during the last decade the employment rate for older workers displayed a U-shaped profile (Table 3). Its increase during the last few years reflects past increases in the level of schooling, which has caused people

Table 1 Old age dependency ratios in the main EU countries

\begin{tabular}{|c|c|c|c|c|c|c|c|}
\hline \multicolumn{8}{|c|}{ Old age dependency ratio } \\
\hline & 2000 & 2005 & 2010 & 2020 & 2030 & 2040 & 2050 \\
\hline $\mathrm{EU}-5^{\mathrm{a}}$ & 25 & 26 & 29 & 32 & 41 & 51 & 53 \\
\hline France & 25 & 25 & 29 & 32 & 39 & 45 & 46 \\
\hline Germany & 24 & 28 & 31 & 34 & 44 & 50 & 49 \\
\hline United Kingdom & 24 & 24 & 25 & 28 & 34 & 38 & 38 \\
\hline Spain & 25 & 25 & 27 & 31 & 41 & 57 & 68 \\
\hline Italy & 27 & 29 & 31 & 37 & 47 & 63 & 65 \\
\hline
\end{tabular}

${ }^{a}$ Unweighted average of the five countries.

Source: United Nations World Population Prospect, 2002 Revision.

Table 2 Italy: age distribution

\begin{tabular}{lcr}
\hline Distribution of the population by age class & 1991 & 2001 \\
\hline $0-14$ & 16.3 & 14.4 \\
$15-24$ & 15.6 & 11.4 \\
$25-44$ & 28.8 & 30.9 \\
$45-64$ & 24.2 & 25.1 \\
$65-79$ & 11.7 & 14.1 \\
$80+$ & 3.3 & 4.1 \\
\hline
\end{tabular}

Source: Eurostat. 
Table 3 Employment rates of workers aged above 50

\begin{tabular}{|c|c|c|c|c|}
\hline \multicolumn{5}{|c|}{ Employment rate of older workers } \\
\hline & 1991 & 1995 & 1999 & 2003 \\
\hline \multicolumn{5}{|l|}{ Total } \\
\hline $50-54$ & 59.3 & 55.1 & 58.9 & 65.8 \\
\hline $55-59$ & 42.2 & 37.1 & 36.8 & 42.8 \\
\hline $60-64$ & 22.7 & 17.9 & 18.6 & 20.2 \\
\hline $65+$ & 4.5 & 3.4 & 3.4 & 3.3 \\
\hline \multicolumn{5}{|l|}{ Men } \\
\hline $50-54$ & 85.5 & 76.5 & 79 & 84.7 \\
\hline $55-59$ & 66.2 & 56 & 51.9 & 57.3 \\
\hline $60-64$ & 36.4 & 29.6 & 31.1 & 30.8 \\
\hline $65+$ & 7.8 & 6.1 & 6 & 5.8 \\
\hline \multicolumn{5}{|l|}{ Women } \\
\hline $50-54$ & 34.4 & 34.3 & 39.1 & 47.3 \\
\hline $55-59$ & 20.7 & 19.2 & 22.5 & 28.9 \\
\hline $60-64$ & 10.1 & 7.5 & 7.2 & 10.4 \\
\hline $65+$ & 2.2 & 1.6 & 1.6 & 1.5 \\
\hline
\end{tabular}

Source: Eurostat.

to enter the labour force later and therefore retire later, as well as the new rules set by the reformed pension schemes.

In fact, the projected reduction in the Italian participation rate is smaller than that estimated for the other large EU economies. According to Burniaux, Duval and Jaumotte, ${ }^{2}$ projected demographic developments imply a fall of more than 6 percentage points in the overall participation rate for Europe, but this will be partly offset by the so-called "cohort effect" defined as "an autonomous increase of female participation corresponding to the gradual replacement of currently older by younger women, leading in the longer term to a homogeneous female population with the same individual characteristics as women who entered the labour force in 2000" and, more significantly, pension reforms already enacted, which are projected to raise the participation rate by 2.5 percentage points. The detailed results are shown in Table 4 .

By these projections, Italian participation rate falls from 60.3 per cent in 2000 to 59.3 per cent in 2025. The one-point decrease is almost four times less than for the other four largest countries (3.9 points). However, this is not a reassuring prospect, since the projected participation rate remains almost 8 percentage points lower than for the other four large EU economies.

This is particularly important if one considers the objectives set by the EU Lisbon Summit in 2000 and refined in the following Stockholm and Barcelona meetings. In particular, the Stockholm Council of March 2001 agreed that at least 70 per cent of the EU population should be in employment by 2010 . One of the most ambitious targets is

\footnotetext{
${ }^{2}$ Burniaux et al. (2004).
} 
Table 4 Projected change in participation rates in selected EU countries

\begin{tabular}{|c|c|c|c|c|c|c|c|c|c|}
\hline \multicolumn{3}{|c|}{$\begin{array}{r}\text { Projected change in overall participatio } \\
\text { Participation rate }\end{array}$} & \multicolumn{5}{|c|}{ Change due to } & \multicolumn{2}{|c|}{$\%$ change in } \\
\hline & 2000 & 2025 & Demography & $\begin{array}{l}\text { Cohort } \\
\text { effect }\end{array}$ & $\begin{array}{l}\text { Unemployment } \\
\text { change }\end{array}$ & $\begin{array}{c}\text { Existing } \\
\text { pension reforms }\end{array}$ & Fertility & Population & $\begin{array}{l}\text { Labour } \\
\text { supply }\end{array}$ \\
\hline $\mathrm{EU}-5^{\mathrm{a}}$ & 68.8 & 65.5 & -6.6 & 2.7 & 0.2 & 0.7 & -0.4 & 6.6 & 0.4 \\
\hline France & 68.0 & 61.3 & -6.9 & 0.4 & 0.1 & -0.1 & -0.2 & 10.0 & -3.4 \\
\hline Germany & 72.2 & 68.7 & -6.4 & 3.0 & 0.0 & 0.1 & -0.3 & 2.5 & -3.7 \\
\hline Spain & 66.7 & 65.9 & -6.6 & 6.1 & 0.1 & 0.2 & -0.6 & 10.7 & 9.1 \\
\hline Italy & 60.3 & 59.3 & -6.8 & 3.0 & 0.6 & 2.5 & -0.3 & -2.2 & -4.2 \\
\hline
\end{tabular}

${ }^{\text {a }}$ Unweighted average of the five countries.

Source: Burniaux et al. (2004). 
to increase the participation rate of older workers by 12 percentage points, and to 50 per cent before 2010 .

Both targets now seem unrealistic, especially for Italy. Later and gradual retirement head the list of measures needed to increase older workers' participation rate. Accordingly, let us begin with a review of the empirical evidence of the reason workers decide to retire.

\section{Microeconometric evidence on the retirement decision}

Aggregate data can provide only tentative explanations of why people retire at a certain age. More convincing evidence can only be gathered by looking at microdata. Policywise, this kind of evidence is particularly important in assessing the extent to which changes in statutory retirement affect effective retirement age, and more broadly in gauging the effects of pension rules' repercussions on expected pension wealth.

One of the first studies on the effects of the reforms enacted during the 1990s on individual decisions to retire was Miniaci's, ${ }^{3}$ which used the 1995 edition of the Bank of Italy's Survey of Household Income and Wealth. He used different methods to model the retirement decisions of men and women. First, Miniaci ran a multinomial logit to find what determines the probability of a person's being retired. For men, not surprisingly, the number of years of contributions is correlated positively with the probability of being retired, but when the regression considers other exit routes from employment, this relationship is weakened. Somewhat counterintuitively, home ownership has a negative correlation with the probability of being retired. Years of schooling also show a negative correlation, which is easily explained by later entry into labour market. The results for women are much less conclusive.

He then estimated a hazard rate, that is, the probability of being retired at a given age, finding that for men this rate has two spikes at 60 and 65, which fits the rules of the pension system. Turning to women he finds spikes at age 55, 60 and 65, consistent with the view that, although they could exit from the labour market earlier, women tend to postpone retirement. Analysis of the determinants of these hazard rates produces the same results as the logit analysis. Moreover, more education leads to later retirement due to the delayed entry into the labour force and a steeper age profile of earnings. This may have important consequences, since the income replacement rate of better educated workers (an ever increasing share of the workforce) has been cut more severely than that of other groups by the 1995 reform. Finally, Miniaci used these estimations to assess the effect of a reduction in the replacement rate on expected retirement age: a 10 per cent cut would increase it on average by 2 months, and a 20 per cent cut by 4.5 . Obviously, the higher the replacement rate, the bigger the impact of a reduction on expected retirement age.

Brugiavini and Peracchi ${ }^{4}$ used individual data from the archives of INPS, the Italian National Social Security Institute, to study the retirement decisions of private sector, nonagricultural employees between 1977 and 1997, focusing on the importance of the

\footnotetext{
${ }^{3}$ Miniaci (1998).

${ }^{4}$ Brugiavini and Peracchi (2003).
} 
financial incentives built into the pension system. They first derived a measure of social security wealth (SSW), defined as the discounted value of the future stream of pension benefits: this measure and its change over time indicate both the expectation of individuals on future income and the workings of the public pension system. Next, they ran probit models with the probability of being retired as the dependent variable and present and expected labour income, SSW and age and cohort dummies as explanatory variables earnings. As expected, future labour income has a negative sign, and SSW and pensionable positive signs.

Finally, Brugiavini and Peracchi ${ }^{5}$ used the estimated coefficient for a counterfactual exercise, trying to assess what the exit rates into retirement and the implied employment rates would be under alternative social security regimes. They considered four scenarios: the old regime, the reforms introduced in 1992 by the Amato Government, those introduced by the Dini Government in 1995 and refined by Prodi in 1997, and finally an actuarial adjustment featuring an early retirement age of 60 and a normal retirement age of 65 , with pensions computed using the average of the last 5 years of contributions, a 60 per cent replacement ratio with an actuarial reduction of 6 per cent per year for early claims, and a corresponding increase for each year by which the claim is deferred. Moving away from the pre-1992 regime means a substantial reduction of the retirement rate for the 50- to 60-year-old age group. The strongest impact is provided by the Dini/Prodi reforms and the actuarial adjustment. Interestingly, however, the Dini/Prodi reform causes an increase in the retirement rate after age 60, due to the sizeable jump in SSW after that age. Only the actuarial adjustment scheme triggers an increase in the employment rate for the over-60s.

Spataro $^{6}$ used the Survey of Household Income and Wealth for 1995 and 1998 (limiting the focus to male workers but splitting the sample into private and public sector employees) to assess the importance of the differences in pension awarding formulas for public and private pensions in the decision to retire and the role of other underlying differences. He used retirement hazard rates, regressing them on a set of economic and sociodemographic variables. Unlike Brugiavini and Peracchi, ${ }^{7}$ he found that the most important factor in the choice to retire for both groups of workers is the income replacement ratio, not the SSW. Eligibility constraints also appear to have good explanatory power, but only when associated with other social factors (which the author defined quite vaguely as "social rules" and "rules of thumb"). The retirement decision in the private sector appears to be tied more closely to eligibility and to an adequate standard of living in old age: in particular, home ownership is a very important explanatory variable. Policywise, these results suggest, in the author's view, that to increase the effective age of retirement, any reform of the pension system should reduce the starting pension award upon attainment of eligibility and make its age profile steeper. Moreover, actuarially increasing benefits should reduce retirement rates.

\footnotetext{
5 Ibid.

${ }^{6}$ Spataro (2003).

${ }^{7}$ Brugiavini and Peracchi, op. cit.
} 


\section{Policy measures}

The goal of increasing the employment of the older workers can be achieved by a mix of policies. The evidence on retirement decisions, as we have seen, shows that tightening eligibility rules and reducing the income replacement rate can have significant effects. However, active labour policy can also do much to increase the employment rate of older workers.

Here we analyze the effects of pension reforms on retirement age. Afterwards, we consider possible alternative measures in Italy and the extent to which they can achieve the aim of higher participation rates.

\section{Further pension reform}

Studies on the sustainability of the Italian pension system abound. ${ }^{8} \mathrm{~A}$ detailed description of all the issues is beyond the scope of this article. It does seem, however, that the curbing of the pension benefits ${ }^{9}$ and the gradual increase of statutory retirement age have lengthened average working careers.

Some indirect evidence of this is simply the average age at retirement, derived from INPS data. For private sector old-age pensions, this was on average 57.6 years in 1993 (60.3 for men and 55.6 for women) and 61.5 years in 2001 (64.5 and 60.1, respectively). For seniority pensions, the increase was smaller: from 53.7 years in 1993 (54 for men and 51.4 for women) to 55.7 years (55.9 and 54.8) in 2001.

This evidence is consistent with the projected effect of past pension reforms on participation rates reported in Table 4 , based on OECD simulations. These reforms mitigate the demographically induced decline in the participation rate for Italy.

Further policy reforms could attenuate or even reverse the decline in the participation rates projected for 2025. In particular, Burniaux, Duval and Jaumotte ${ }^{10}$ asses the presumed impact of three possible pension reforms on labour force participation by older workers, using the econometric estimates in Duval ${ }^{11}$ and Jaumotte. $^{12}$ The changes considered are: (i) removal of early retirement schemes; (ii) institution of actuarial neutrality of old-age pension systems; and (iii) raising the standard age to 67 years, the highest now in effect in any OECD country.

The results (Table 5) show that for Italy these reforms prevent the projected decline in participation rate and would actually raise the rate from 60.3 per cent in 2000 to 61.4 per cent in 2025. Not surprisingly, actuarial neutrality has the largest effect raising by 1.6 percentage points the projected participation rate; the effect of raising the standard retirement age to 67 years is much smaller ( 0.5 percentage points).

However, the projected Italian participation rate in 2025 (61.4 per cent) is only marginally higher than that projected for France even in the absence of any further pension reform. The gap with the other four main EU countries would become very

\footnotetext{
${ }^{8}$ See for example, Brugiavini (1999) and Franco (2002).

${ }^{9}$ See Fornero and Castellino (2001) for a quantitative estimation of the changes in pension income.

${ }^{10}$ Burniaux et al. (2004).

${ }^{11}$ Duval (2003).

${ }^{12}$ Jaumotte (2003).
} 
The Geneva Papers on Risk and Insurance - Issues and Practice

718

Table 5 Effects of pension reforms on participation rates in selected EU countries

Impact of pension reforms on participation rate, 2000-2025

\begin{tabular}{lcccccc} 
& & \multicolumn{5}{c}{ Measures } \\
\cline { 3 - 6 } & $\begin{array}{c}\text { Change with } \\
\text { no policy }\end{array}$ & $\begin{array}{c}\text { Removal of } \\
\text { early retirement }\end{array}$ & $\begin{array}{c}\text { Actuarial } \\
\text { neutrality }\end{array}$ & $\begin{array}{c}\text { Delaying } \\
\text { retirement age }\end{array}$ & $\begin{array}{c}\text { Total } \\
\text { impact }\end{array}$ & $\begin{array}{c}\text { Participation rate } \\
\text { with reforms }\end{array}$ \\
\hline EU-5 $^{\text {a }}$ & -3.3 & 0.6 & 1.3 & 0.7 & 2.6 & 68.1 \\
France & -6.7 & 0.6 & 1.3 & 1.3 & 3.2 & 64.5 \\
Germany & -3.5 & 1.0 & 0.5 & 0.5 & 2.0 & 70.7 \\
United Kingdom & -4.5 & 0.4 & 0.7 & 0.6 & 1.7 & 73.8 \\
Spain & -0.8 & 1.0 & 2.4 & 0.6 & 4.0 & 69.9 \\
Italy & -1.0 & 0.0 & 1.6 & 0.5 & 2.1 & 61.4 \\
\hline
\end{tabular}

${ }^{a}$ Unweighted average of the five countries.

Source: Burniaux et al. (2004).

large if they decided to put their publicly financed pillar of the pension system on a sound footing. In this case, their projected participation rate would rise to nearly 70 per cent, more than 8 percentage points higher than Italy.

Against this background, let us now consider alternative measures complementary to the indispensable pension reforms that would help increase the participation rate.

\section{Active labour-market policies}

As Marano and Sestito ${ }^{13}$ have noted, financial incentives for job creation are targeted almost exclusively to new hirings, while programmes of occupational reorientation and lifelong learning are largely neglected. Financial incentives now compensate almost all hirings of people under 25 and only one of every seven hires of people older than 50. The 2003 law reforming the labour market does introduce some incentives for older workers trying to re-enter the labour market. However, it also raises the age ceiling for apprenticeship schemes to 29, implying that jobs for older unemployed workers are not a high priority. More broadly, the institutional framework of labourmarket regulation has incentives only for younger workers.

A recent report commissioned by the Ministero del Lavoro ${ }^{14}$ identifies the bias in the incentive scheme, which involves both demand and supply. On the demand side, any policy to increase the employment of the elderly inevitably conflicts with the measures in favour of firms in crisis or restructuring. Layoffs affect elderly workers disproportionately, and in the past, they were greatly facilitated by widespread recourse to early retirement.

If retirement is caused by company downsizing or industry-wide contraction rather than individual choice, supply-side incentives for individuals are clearly useless. And as labour-market demand-side measures to sustain firms are increasingly difficult to

\footnotetext{
${ }^{13}$ Marano and Sestito (2004).

${ }^{14}$ Ministero del Lavoro (2003).
} 
Table 6 Part-time employment

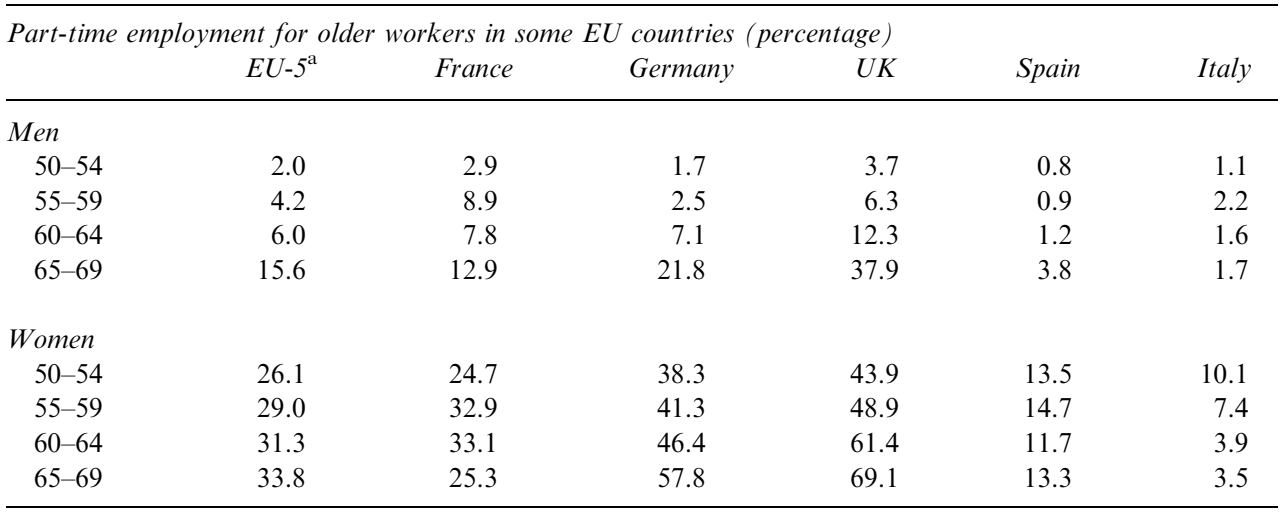

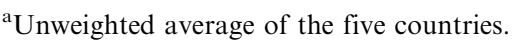

Source: Eurostat Labour Force Survey (1997).

implement and of questionable efficacy, the effort should be to institute programmes of occupational upgrading and lifelong learning for older workers.

According to a recent survey ${ }^{15}$ such initiatives are virtually non-existent in Italy, both at the national and regional level. Labour-market supply-side factors consist in financial incentives for older workers to keep working, which in Italy depend almost exclusively on the design of the pension system.

\section{Gradual retirement through flexible employment}

In a detailed case study for some European countries, Delsen and Reday-Mulvey ${ }^{16}$ show that older workers would prefer a gradual transition to retirement through the use of part-time work or other flexible forms of employment. Transcending the flat alternative between full-time work and retirement could thus be effective in raising the employment rates of older workers.

Such new schemes, although not yet widespread, are becoming common in the main EU countries, ${ }^{17}$ but Italy is lagging behind in offering opportunities for part-time jobs for older workers. Employment rates are far below the European average, or below countries facing similar ageing problems like France and Germany. The evidence for 1997 reported in Morris and Mallier (Table 6) is that only 1.1 per cent of male workers aged 50-54 years had part-time jobs, against a European average of 2.1 per cent. For older workers, aged 55-59 years, the rate for Italy was 2.2 per cent, against 4.1 per cent for Europe. For women, the gap was even wider: for the 50-54 age group, the EU-15 average was 31.1 per cent more than three times the 10 per cent registered in Italy. This mainly reflects the low female employment rate in Italy.

\footnotetext{
15 Porcari et al. (2004).

${ }^{16}$ Delsen and Reday-Mulvey (1998).

${ }^{17}$ Morris and Mallier (2003).
} 


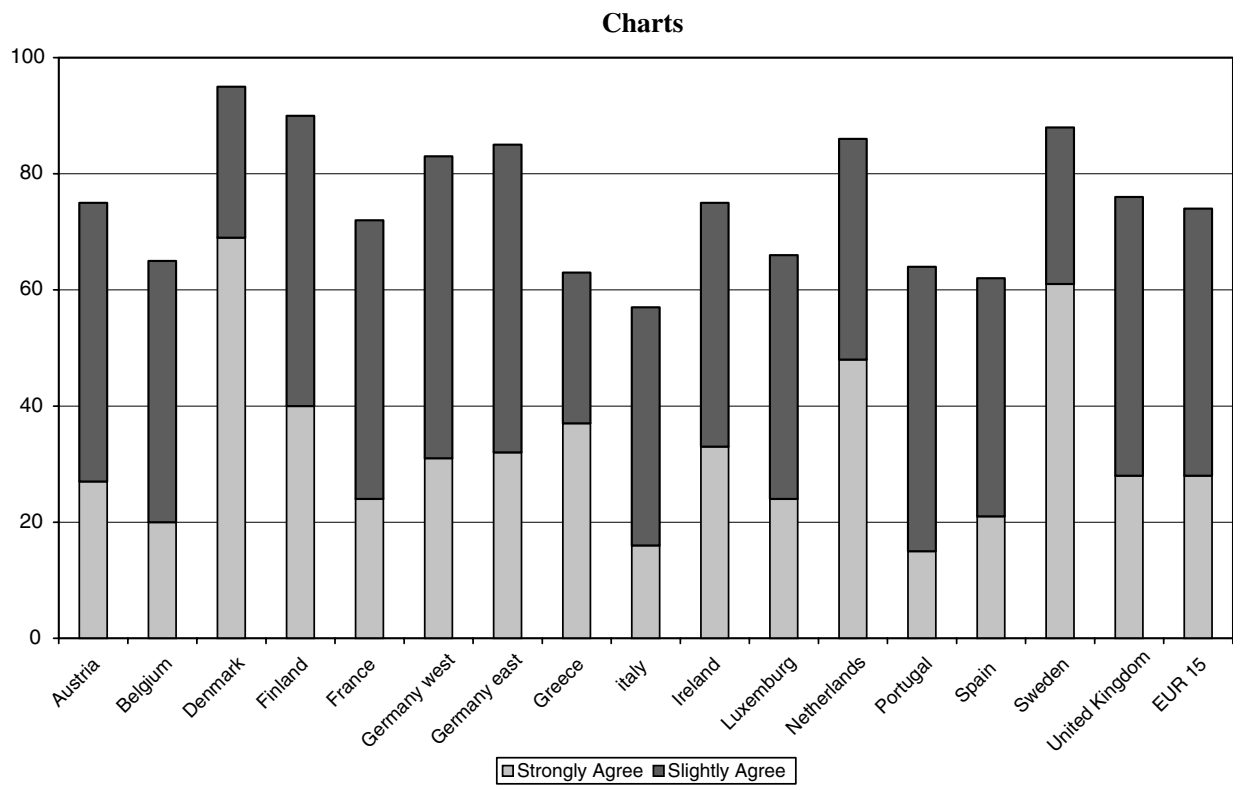

Figure 1. Percentage of working agreeing to gradual retirement (taken from Geneva Association Information Newsletter, The Four Pillars no. 31 (August 2002)).

Survey evidence (so far, quite limited) suggests that the scope for gradual, flexible retirement is ample. The Eurobarometer survey of October 2001 contained a series of questions on specific ideas for the transition from work to retirement. The view that "older workers should be allowed to retire gradually from work (e.g. to combine a partial pension with reduced work)" enjoyed very broad support: almost three out of four respondents agreed, 46 per cent moderately and 28 per cent strongly, while only 17 per cent disagreed (for the results see Figure 1). The support was strongest in Denmark, Sweden and the Netherlands, all countries that already have partial pension schemes in place. In Italy support for the proposal was the weakest in Europe, even though most respondents generally favoured gradual retirement measures.

An interesting finding is the strong (0.8) correlation between the propensity to gradual retirement and the overall labour participation rate in EU countries (Figure 2). Of course, the explanation of this fact and its policy implications are not clear or unambiguous. On the one hand, active labour-market policy to increase participation rates may conceivably also foster individual preferences for gradual retirement. On the other hand, the propensity to retire gradually might be influenced by psychological, workplace, health, gender and socio-economic factors, so that successful policies to increase participation need to recognize that in some countries (including Italy) some share of workers prefer leisure to work.

However, there is indirect evidence that, if given the right incentives, workers are willing to postpone retirement. In late 2003, the Italian Government introduced a scheme to induce some groups of workers to postpone retirement, the so-called 


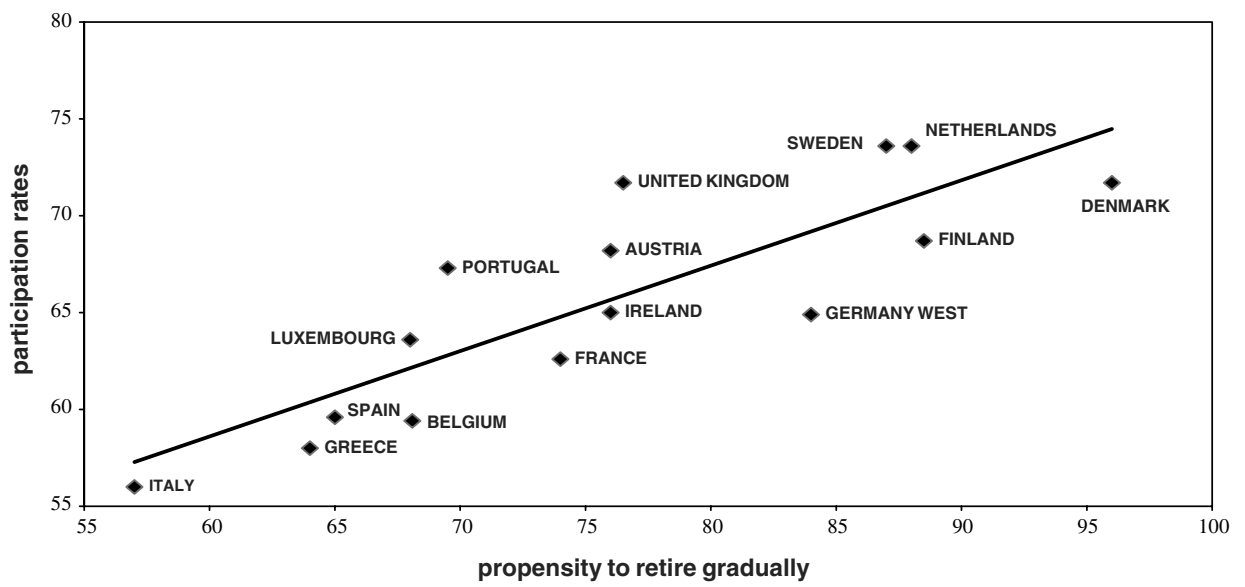

Figure 2. Propensity for gradual retirement and participation rate in EU countries.

"superbonus". The measure is open to private sector employees who by 2007 will have achieved eligibility for the seniority pension. If they opt to keep working, their net wage is augmented by their contribution to social security (32.7 per cent of the gross wage), tax-exempt. As they stop contributing to the pension system, their pensionable earnings are "frozen" at the moment they opt for the scheme. The "superbonus" was launched in October 2004 and has been quite popular; by mid-January 2005, nearly 5 per cent of the eligible workers had opted to postpone retirement.

The efficacy of such a measure for the financial sustainability of the social security system has been questioned. Boeri and Brugiavini, ${ }^{18}$ for example, have observed that the programme appealed mostly to workers who had already decided not to retire anyway and who had high incomes, since they get the largest tax break. The data published by the Ministry of Welfare show that 40 per cent of the applications came as soon as the law instituting the superbonus went into effect. What is more, nearly three-fourths of the workers declared eligible for the "superbonus" had already achieved pension eligibility before this measure. Nevertheless, this evidence does not disconfirm the hypothesis that the measure achieved some increase in the retirement age.

Looking ahead, the most important issue is overcoming the one-off nature of the superbonus. A useful policy would be to promote private defined-contribution pension schemes for workers who choose to retire later. On the tax side, this could be achieved by means of special treatment of contributions and benefits, such as making contributions at least partially deductible. The available pension products should be improved, taking into account the relative short contribution horizon and the pensioners' need for a certainty over their pension wealth or stream of income; this requires some guarantee of minimum returns.

18 Boeri and Brugiavini (2005). 


\section{Conclusions}

The impact of ageing on the labour force will be more severe in Italy than in the rest of Europe, as an adverse demographic trend is compounded by a system of incentives penalizing the employment of older people.

The employment rate for Italians over 50 years of age has declined steadily in the 1980 s and the early 1990s, owing to the characteristics of the pension system and to a number of industrial crises, in which firms restructuring entailed massive layoffs of older, low-skilled workers. The situation improved during the second half of the 1990s due to changes in the composition of the workforce and the initial effects of the pension reforms. However, the gap in employment rates with the rest of the EU is still quite wide, and the Commission's objective of a 50 per cent rate for people aged 55-64 does not look realistic for Italy.

Individual choices on retirement age depend largely on the generosity of the pension scheme, although econometric analysis has also detected other relevant factors such as cohort, education and family. Simulations based on these estimates show that curbing pension benefits and imposing stiffer eligibility requirements can have a substantial impact on retirement age.

In Italy the only measures that have significantly raised retirement age have been the successive pension reforms. Between 1992 and 2003, the pension system was practically revolutionized. Eligibility requirements have been progressively stiffened, both for age and years of contribution, while the new award formulas have reduced the replacement rate and curbed the rise of pension outlays over time. Further pension reform promoting recourse to private pensions could have an effect on the retirement age, over and above their natural contribution to the financial sustainability of the public pension system.

However, encouraging later exit from the workforce might entail a wider range of policy measures, concerning not only the pension system but also the labour market. Incentives to fight unemployment do exist but are targeted almost exclusively to young workers and recent labour-market reforms have confirmed this preference. Financial incentives for the hiring of older workers or the long-term unemployed might be an effective strategy to lengthen the average working life.

A more gradual transition from work to retirement can be attained through more flexible forms of employment, such as part-time. In this regards, Italy now lags behind the other European countries in these measures. A further development of private retirement plans should be envisaged, with schemes according a favourable tax treatment to older workers and tailoring the pension products to their needs.

\section{References}

Boeri, T. and Brugiavini, A. (2005) 'Cosa resta della riforma della previdenza', from http://www.lavoce.info/ news/view.php?id $=13 \& \mathrm{cms} \_$pk $=1398 \&$ from $=$ index accessed 24 February 2005.

Brugiavini, A. (1999) 'Social security and retirement in Italy', in J. Gruber and D. Wise (eds) Social Security and Retirement around the World, NBER Conference Report series, Chicago and London: University of Chicago Press.

Brugiavini, A. and Peracchi, F. (2003) 'Social security wealth and retirement decisions in Italy', Labour 17(Special Issue): 79-114. 
Burniaux, J.-M., Duval, R. and Jaumotte, F. (2004) Coping with ageing: A dynamic approach to quantify the impact of alternative policy options on future labour supply in OECD countries, OECD Economics Department Working Papers No. 371, Paris.

Delsen, L. and Reday-Mulvey, G. (eds) (1998) Gradual Retirement in OECD Countries, Aldershot, U.K.: Ashgate.

Duval, R. (2003) The retirement effect of old-age pension and early retirement schemes in OECD countries, OECD Economics Department Working Papers No. 370, Paris.

Eurostat (1997) Labour Force Survey, Brussels.

Fornero, E. and Castellino, O. (eds) (2001) La riforma del sistema previdenziale italiano, Bologna: Il Mulino.

Franco, D. (2002) 'Italy: A never-ending pension reform', in M. Feldstein and H. Siebert (eds) Coping with the Pension Crisis - Where does Europe Stand?, Chicago: Chicago University Press.

Jaumotte, F. (2003) Female labour force participation: Past trends and main determinants in OECD countries, OECD Economics Department Working Papers No. 367, Paris.

Marano, A. and Sestito, P. (2004) 'Older workers and pensioners: The challenge of ageing on the Italian public pension system and labour market', in E. Fornero and P. Sestito (eds) Pension System: Beyond Mandatory Retirement, Cheltenham: Edgar Elwin.

McMorrow, K. and Roeger, W. (2003) Economic and financial market consequences of ageing populations, European commission, Economics Working Papers No. 182, Brussels.

Ministero del Lavoro (2003) 'Scelte Lavorative e di Pensionamento degli Anziani in Italia', Rome.

Miniaci, R. (1998) Microeconometric analysis of the retirement decision: Italy, OECD Economics Department Working Papers No. 205, Paris.

Morris, D. and Mallier, T. (2003) 'Employment of older people in the European union', Labour 17(4): 623-648.

Porcari, S., Riccone, P. and Folini, G. (2004) 'I lavoratori adulti tra programmazione regionale e politiche locali', ISFOL Monografie sul mercato del lavoro e le politiche per l'impiego $\mathrm{N}^{\circ} 12 / 2004$.

Spataro, L. (2003) Social security and retirement decisions in Italy, Working Paper No. 1/2003, Department of Economics, University of Pisa.

Turner, D., Giorno, C. and De Serres, A. (1998) The macroeconomic implications of ageing in a global context, OECD, Economics Department Working Papers No. 193, Paris.

\section{About the Authors \\ Dario Focarelli is Chief Economist at ANIA (Italian Association of Insurers). Paolo Zanghieri is Economist at ANIA.}

